\title{
THE COLORIMETRIC ESTIMATION OF FREE AND COMBINED CHOLESTEROL IN SERUM
}

\author{
By Funimasa YANAGISAWA and MASAKI MIZOKOSHI \\ Research Institute for the Influences of Atomic Bomb, Hiroshima Branch of the National \\ Institute of Health of Japan, Hiroshima \\ (Received for publication, April 1, 1950)
}

This paper describes a simple and quick method for determination of free and combined cholesterol in serum. This method requires less hours to complete the determina* tion as compared to the older method which requires at least twenty-hours. The total choleterol is first determined by Zuckerman's method(1). Combined and free cholesterol are determined on the chloroform extract with the aid of digitonin. Free cholesterol is in the precipitates with digitonin and the combined cholesterol remains in solution. This method is quicker and more convenient than the method of Shoenheimer(2), Sperry(3), or Pijoan(4).

\section{REAGENTS}

$5 \%$ sulfuric acid solution $\left(5 \mathrm{~g}\right.$ of concentrated $\mathrm{H}_{2} \mathrm{SO}_{4}$ to $100 \mathrm{ml}$ of $\mathrm{H}_{2} \mathrm{O}$ ).

Chloroform (analytical grade).

Concentrated sulfuric acid.

Acetic anhydride (analytical grade).

Acetic anhydride-sulfuric acid reagent. Mix cautiously 4 parts of cold acetic lanhydride and 1 part of cold sulfuric acid $\left(0-5^{\circ} \mathrm{C}\right)$ in a stoppered Erlenmeyer flask placed in ice. Use immediately after mixing (Kingsley's method (5)).

Digitonin solution $(0.5 \mathrm{mg}$ digitonin dissolved in $100 \mathrm{ml}$ of $50 \%$ alcohol $)$.

Acetic acid-methyl alcohol solution ( 1 to 3 ratio by volume). Cholesterol standard $(0.02 \mathrm{mg}$ per $\mathrm{ml})$ $40 \mathrm{mg}$ of cholesterol is dissolved in chloroform and diluted exactly to $200 \mathrm{ml}$ and $10 \mathrm{ml}$ of this solution is diluted up to $100 \mathrm{ml}$ with chloroform.

\section{PROCEDURE}

I. Total cholesterol.

To $0.3 \mathrm{ml}$ of blood serum in $25 \mathrm{ml}$ test tube is added $12 \mathrm{ml}$ of $5 \%$ sulfuric acid and exactly $15 \mathrm{ml}$ of chloroform from a burette. The tube is stoppered tightly with rubber stopper which has been soaked in chloroform for a half hour and dried on gauge. The content is then shaken on a shaking machine for a half hour and centrifuged. The water layer and the protein in the chloroform-water interface are removed by suction leaving the chloroform extract. If protein sticks to glass-wall, it is stirred with a glass-rod., and protein comes to the surface. Then it can be easily removed by glass-rod. For the determination of total cholesterol, $2 \mathrm{ml}$ of acetic anhydride-sulfuric acid is added to $5 \mathrm{ml}$ aliquot portion of chloroform extract and the mixture is shaken vigorously. Aftèr mixing, read the density of the color developed at 4 to 7 minutes' interval to obtain the maximum reading if the temperature of the reaction mixture is $25^{\circ} \mathrm{C}$, at 10 to 15 
minutes' interval at $20^{\circ} \mathrm{C}$. The optical density is determined on a Evelyn photoelectric colorimeter using No. 620 filter.

II. Combined cholesterol.

To another $5 \mathrm{ml}$ aliquot portion of chloroform extract is added $1 \mathrm{ml}$ of digitonin solution and heated in a water bath at $70^{\circ} \mathrm{C}$ to complete dryness. Thereafter $5 \mathrm{ml}$ of warm chloroform is added and after 20 minutes filtered. The volume of the filtrate is adjusted to $5 \mathrm{ml}$ with chloroform and $2 \mathrm{ml}$ of acetic anhydride-sulfuric acid is added. The color is developed and determined as in the case of total cholesterol.

III. Free cholesterol.

To the remaining precipitate is added $2 \mathrm{ml}$ of warm acetic acid methyl alcohol solution and heated in a water bath at $70^{\circ} \mathrm{C}$ to complete dryness. To this is added $5 \mathrm{ml}$ of chloroform and shaken vigorously and filtered after 20 minutes. The volume of the filtrate is adjusted to $5 \mathrm{ml}$ with chloroform and added with $2 \mathrm{ml}$ of acetic anhydride-sulfuric acid. The color develops and its density is determined as in the cass of total cholesterol.

\section{STANDARD AND BLANK}

The standard is read at the same time as the unknown. Add 1,2,3,4, and $5 \mathrm{ml}$ of working cholesterol standard to photometer cuvettes and dilute each to $5 \mathrm{ml}$ with chloroform. Add $2 \mathrm{ml}$ of ice-cold fresh acetic anhydride-sulfuric acid, mix, and read the color as directed in "Procedure".

The blank consists of $2 \mathrm{ml}$ of acetic anhydride-sulfuric acid and $5 \mathrm{ml}$ of chloroform.

\section{CALCUlation}

The concentration of cholesterol in the unknown can be estimated by the standard curve. Since this curve is a straight line, the formula below will yield the cholesterol values in milligrams per cent when serum is used.

\footnotetext{
$\frac{\text { Density of unknown }}{\text { Density of standard }} \times \mathrm{mg}$ in standard $=\mathrm{mg}$ per cent of cholesterol
}

\section{RESULTS}

The results obtained are listed in Table 1 . Theoretically the determined value of total cholesterol should be equal to the sum of combined cholestrol and free cholesterol, but practically the former is $1-5 \mathrm{mg}$ larger than the latter.

Table 1 .

\begin{tabular}{c|c|c|c|c}
\hline Sample & $\begin{array}{c}\text { Total } \\
\text { cholesterol }\end{array}$ & $\begin{array}{c}\text { Combined } \\
\text { cholesterol }\end{array}$ & $\begin{array}{c}\text { Free } \\
\text { cholesterol }\end{array}$ & $\begin{array}{c}\text { Combined C. } \\
\text { +Free C. }\end{array}$ \\
\cline { 2 - 3 } & 132 & 87 & 46 & 133 \\
2 & 139 & 76 & 61 & 137 \\
3 & 153 & 74 & 69 & 143 \\
4 & 140 & 76 & 60 & 136 \\
5 & 116 & 61 & 52 & 113 \\
\hline
\end{tabular}

(The values are expressed in terms of milligrams of cholesterol in $100 \mathrm{ml}$ of serum. Each value is the average of duplicates.) 
Table 2 shows the result after adding the cholesterol standard solution to the serum.

Table 2

\begin{tabular}{|c|c|c|c|c|c|}
\hline Sample & $\begin{array}{l}\text { Cholesterol } \\
\text { added* }\end{array}$ & $\begin{array}{c}\text { Total } \\
\text { cholesterol }\end{array}$ & $\begin{array}{l}\text { Combined } \\
\text { cholesterol }\end{array}$ & $\begin{array}{c}\text { Free } \\
\text { cholesterol }\end{array}$ & $\begin{array}{l}\text { Combined C. } \\
\text { +Free C. }\end{array}$ \\
\hline 1 & $\overline{100 \mathrm{mg}}$ & $\begin{array}{l}167 \\
263\end{array}$ & $\begin{array}{l}88 \\
97\end{array}$ & $\begin{array}{r}72 \\
152\end{array}$ & $\begin{array}{l}160 \\
249\end{array}$ \\
\hline 2 & $\overline{100}_{\mathrm{mg}}$ & $\begin{array}{l}143 \\
238\end{array}$ & $\begin{array}{l}87 \\
92\end{array}$ & $\begin{array}{r}53 \\
140\end{array}$ & $\begin{array}{l}140 \\
232\end{array}$ \\
\hline 3 & $\overline{50} \mathrm{mg}$ & $\begin{array}{l}149 \\
192\end{array}$ & $\begin{array}{l}81 \\
87\end{array}$ & $\begin{array}{r}68 \\
101\end{array}$ & $\begin{array}{l}149 \\
188\end{array}$ \\
\hline
\end{tabular}

* This amount of cholesterol is added to $100 \mathrm{cc}$ of serum.

The result of comparison of the new method with Sperry's method is shown in Table 3.

Table 3.

\begin{tabular}{c|c|c|c} 
Sample & Methods & $\begin{array}{c}\text { Total } \\
\text { cholesterol }\end{array}$ & $\begin{array}{c}\text { Free } \\
\text { cholesterol }\end{array}$ \\
\cline { 2 - 3 } 1 & $\begin{array}{c}\text { New method } \\
\text { Sperry's method }\end{array}$ & 232 & 66 \\
223 & 64 \\
\cline { 2 - 3 } 2 & New method & 153 & 74 \\
& Sperry's method & 148 & 72 \\
\hline \multirow{3}{*}{3} & New method & 116 & 52 \\
& Sperry's method & 117 & 53 \\
\hline
\end{tabular}

As shown in Table 3 each value of free cholesterol obtained by two methods is almost the same, and the result comparing this method with Pijoan's method is shown in Table 4.

Table 4.

\begin{tabular}{c|c|c}
\hline Sample & $\begin{array}{c}\text { Pijoan's method } \\
\text { cholesterol }\end{array}$ & $\begin{array}{c}\text { New method } \\
\text { cholesterol }\end{array}$ \\
\hline 1 & 135 & 137 \\
2 & 120 & 124 \\
3 & 126 & 128 \\
4 & 263 & 273 \\
5 & 184 & 189 \\
\hline
\end{tabular}

Pijoan's method is rather complicated and sometimes erronoeus.

\section{SUMMARY}

By modifying the Zuckerman's method of cholesterol determination, the writer found a rapid estimation method of free and combined cholesterol. 


\section{REFERENCES}

1) Zuckerman, J.L. and Natelson, S.: A convenient and rapid procedure for total cholesterol estimation using an acid celoroform extraction. J. Lab. Clin. Med., 33, 1322, 1948.

2) Schoenheimer, R. and Sperry, W.M.: Micromethod for determination of free and combined cholesterol. J. Biol. Chem., 160, 745, 1934.

3) Sperry, W. M.: A micromethod for the determination of total and free cholesterol. Am. J. Clin. Path., Tech. Suppl., 2, 91, 1938.

4) Pijoan, M. and Walter C.W.: A micromethod for the determination of blood cholesterol. J. Lab. Clin. Med., 22, 968, 1937.

5) Kingsley, G.R. and Schaffert, R.R.: Determination of free and total cholesterol by direct chloroform extraction. J. Biol. Chem., 180, 315, 1949.

\section{Errata}

\begin{tabular}{|c|c|c|c|c|}
\hline Vol. & No. & Page & Line & \\
\hline 2 & 3 & 119 & 11 & For 1924 read 1942. \\
\hline " & ". & 121 (Table 1) & 3 & For Streptmicin read Streptomycin. \\
\hline " & $" 1$ & 123 (Table 3) & 12 & For concetration read concentration. \\
\hline$"$ & " & 124 & 6 & For very read vary. \\
\hline$" 1$ & " & 125 & 20 & $\begin{array}{l}\text { After "appear" insert "in the excretions } \\
\text { than streptomycin. On this point, streptomycin } \\
\text { appears". }\end{array}$ \\
\hline " & " & 129 (References 2) & 5 & For Japanese read English. \\
\hline$"$ & 4 & 187 & 22 & For $0.5 \mathrm{mg}$ read $5.0 \mathrm{mg}$. \\
\hline " & " & " & 23 & For and read any. \\
\hline
\end{tabular}

